
3 Research Square
Preprints are preliminary reports that have not undergone peer review.
They should not be considered conclusive, used to inform clinical practice,
or referenced by the media as validated information.

\title{
Applying the Behaviour Change Wheel: insights into the development of the breastfeeding component of the Baby Buddy smartphone app
}

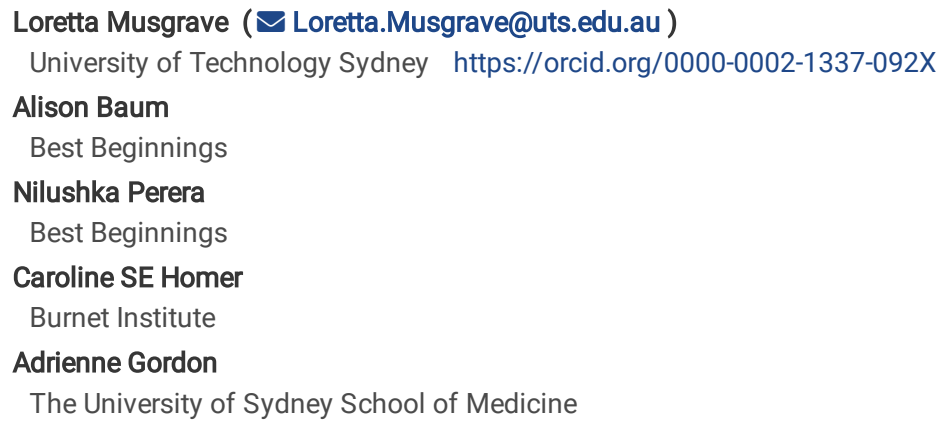

Research article

Keywords: breastfeeding, apps, digital health, smartphone applications, behaviour change wheel, digital behaviour change intervention, UNICEF BFI DOI: https://doi.org/10.21203/rs.3.rs-33159/v1

License: (c) (i) This work is licensed under a Creative Commons Attribution 4.0 International License. Read Full License 


\section{Abstract}

\section{Background}

Breastfeeding plays a major role in the health of mothers and babies and has the potential to positively shape an individual's life both in the short and longterm. In the United Kingdom (UK), despite around $81 \%$ of women initiating breastfeeding, only $1 \%$ of women breastfeed exclusively to 6 months as recommended by the World Health Organisation (WHO). Women who are socially disadvantaged and younger, are less likely to breastfeed at 6-8 weeks postpartum. One strategy that aims to improve these statistics is the Baby Buddy app which has been designed, developed and implemented by the UK charity Best Beginnings to be a universal intervention to help reduce health inequalities, including breastfeeding.

The aim was this study was to retrospectively examine the development of Baby Buddy as a Digital Behaviour Change Intervention (DBCl) that may increase breastfeeding self-efficacy, knowledge and confidence to positively impact breastfeeding rates and duration.

\section{Methods}

The study used a three-stage process evaluation, triangulation methods and formalised tools. A retrospective evaluation was done after the app was developed and embedded. The app development process and content were reviewed by applying the Behaviour Change Wheel (BCW), Capability, Opportunity and Motivation-Behaviour (COM-B) system and Behaviour Change Techniques Taxonomy (BCTTV1). A clear understanding of behaviours that need to change in pregnancy to improve breastfeeding knowledge, self-efficacy and confidence was sought.

\section{Results}

Retrospective application of the BCW, COM-B and BCTTV1 confirmed that the Baby Buddy app is a well-designed DBCl, appealing particularly to younger women and women for whom English is not their first language. The Best Beginnings charity used several frameworks and guidelines and the use of these instruments contributed to the good design and development of Baby Buddy. Content analysis verified that the resources developed could affect attitudes and assist women to make decisions, and perceptions of self-efficacy in relation to breastfeeding.

\section{Conclusions}

Baby Buddy has the potential to improve breastfeeding knowledge, confidence and self-efficacy. Future research should assess which components of the app are most effective on breastfeeding and whether it has an impact on clinical health outcomes for mothers and babies.

\section{Background}

Research shows that a healthy start to life is crucial for improving life-long health outcomes $(1,2)$. Despite universal public funding for pregnancy care and targeted antenatal and postnatal programs, the United Kingdom (UK) has huge inequalities in perinatal outcomes for women and children from minority ethnic communities, those who are socially disadvantaged or who become pregnant in their teenage years $(1,2)$. Breastfeeding is well recognised to positively impact and shape the lives of both the mother and baby both in the short and the long term.

Breastmilk is nutritionally balanced and helps protect infants and children from infections (1). A meta-analysis of six high-quality studies showed that 'ever breastfeeding' (infants who have breastfeed at least once) was associated with a 36\% reduction in sudden infant deaths (95\% Cl: 19-49\%) (2). Breastfed babies also have a lower chance of childhood leukaemia and allergies, and are less likely to develop diabetes or become overweight when they are older (3). Breastfeeding also benefits mothers, enhancing bonding between mother and child and is also associated with a lower risk of developing breast and ovarian cancer, osteoporosis, diabetes and cardiovascular disease (3). Longer periods of breastfeeding are also associated with a $26 \%$ reduction in the odds of overweight or obesity (95\% Cl: 22-30) (4). The Lancet breastfeeding series recommends scaling up breastfeeding interventions and monitoring trends in breastfeeding practices, as well as improving interventions and breastfeeding practices that support women in their homes and communities (1, 3).

The UK National Infant Feeding Survey (2010) showed that, despite around $81 \%$ of women initiating breastfeeding, $34 \%$ of babies receive any breastmilk at six months (only $1 \%$ are exclusively breastfed) and the country ranks lowest in the world for breastfeeding at 12 months of age (5). The aggregate breastfeeding rate for England (Quarter 2 2019/20) at 6-8 weeks is 48.1\% (with confidence intervals of 47.8-48.3\%). (6). As a response to falling breastfeeding rates, the UK Public Health England (PHE) in collaboration with UNICEF UK, has produced several policies and resources in line with the 'Baby friendly initiative'. It is hoped that initiatives that promote breastfeeding will augment women's and children's health and support maternal-infant bonding $(7,8)$.

In 2007, the Best Beginnings charity commenced market research leading to the co-creation of resources with parents, the UK Department of Health and UNICEF UK. Two breastfeeding resources were created; the 'Bump to Breastfeeding' DVD and the 'Small Wonders" DVD for parents of premature and sick babies. These resources were developed to raise awareness of the benefits of breastfeeding whilst also acknowledging its challenges. The aim was to increase breastfeeding initiation rates in targeted areas of the UK, increase rates beyond the first week and provide parents with the motivation to breastfeed exclusively for six months. Since the 2008 launch, over two million copies of the DVD have been distributed. In 2014, Best Beginnings launched Baby Buddy, a smartphone app aimed to support parents and parents-to-be from conceptions to the first six months of life. Its overarching aim was ensuring that parents of all backgrounds have the knowledge and confidence to look after their own mental and physical health and maximise their children's health and language development. More recently, the Nurturing Care Framework has clearly articulated five components; good health, responsive care giving, opportunities to learn, adequate nutrition, safety and security, all of which are promoted through text and video content within Baby Buddy. Current evidence suggests that pregnant women are more likely to download pregnancy-related apps and find them useful sources of information and support rather than using older technologies 
such as DVD or written material $(9,10)$. This trend towards the use of smartphones opens up an opportunity to reach those women who are less likely to engage with health care providers or are yet to do so $(9-11)$.

Baby Buddy was designed to focus on the 'window of opportunity' from pre-conception to one year of age in which the foundations for a healthy childhood are laid. The app is cost free, accredited by the NHS, endorsed by many organisations including the Royal College of Midwives, the Royal College of Obstetricians and Gynaecologists, Royal College of Paediatrics and Child Health, and can be easily accessed on both Android and iOS devices. Baby Buddy is intended to be used by parents of all backgrounds and to be particularly engaging for those who may have difficulty connecting with health services, due to language, age, culture or socioeconomic barriers. It aims to build confidence and self-efficacy, and promote good parental-infant bonding and attachment. It contains over 300 videos including all the videos from the "From bump to breastfeeding DVD" and videos on maternal mental health and provides engaging and interactive daily information as well as a host of other interactive features. Baby Buddy is designed to improve physical, emotional and social health and encourage positive lifestyle behaviour choices. It also aims to improve self-confidence, knowledge and understanding of how to manage as a new parent and encourages realistic expectations. The app intends to enhance the link between parents and health care providers and promotes better engagement, communication and shared decision making with parents (12).

Although apps are accessed by many women of reproductive age and may be able to support health behaviour change, few apps have used behaviour change theory in their development. The principal aim of the study was to describe the context, development and activities undertaken with respect to the breastfeeding component of the Baby Buddy smartphone app as a DBCI.

\section{Methods}

This project reviewed summary reports of data from 2008 to 2019. These reports were previously prepared by Best Beginnings to inform the design of Baby Buddy (Additional file 1). Evaluation reports and ongoing studies that evaluated Baby Buddy as an intervention, or sought to understand the embedding of Baby Buddy into UK NHS maternity services, were also reviewed.

Application of the Behaviour Change Wheel (BCW), Capability, Opportunity and Motivation-Behaviour (COM-B) system and Behaviour Change Techniques Taxonomy (BCTTV1) involved a three stage, eight step process (Fig. 1). Two guidebooks containing worksheets were used to deconstruct and retrospectively analyse the development process and the breastfeeding components within the Baby Buddy app $(13,14)$. The BCW was chosen as it was developed from 19 frameworks and provides a systematic approach that acknowledges the importance of behavioural theory in the design of interventions (13). The research was conducted between November 2017 and December 2018.

Stage one was to gain an in-depth understanding of breastfeeding as a target behaviour. An examination of the qualitative data provided by Best Beginnings, related to the breastfeeding context and activities, was undertaken using the BCW, Capability, Opportunity and Motivation-Behaviour (COM-B) tool (14). The research team used this model to identify the barriers and enablers related to breastfeeding.

Stage two was to determine which intervention components should be used and if they were suitable in the breastfeeding context. The Theoretical Domains Framework (TDF) was utilised to expand on the COM-B components (14).

Stage three identified which Behavioural Change Techniques (BCTs) had been used for breastfeeding based on the intervention functions identified. We used the APEASE $(13,14)$ criteria to analyse the evidence received from Best Beginnings in relation to the DBCls used. These steps provided insight into how the content was developed and implemented $(13,14)$.

\section{Description Of Evaluation Tools Used}

Frameworks and tools were applied retrospectively to the data provided (Additional file 1). Each component of Baby Buddy was considered against the DBCl template to evaluate the context (how the app was developed, tested and evaluated using six factors) and activities undertaken (concept, knowledge, development, testing, implementation and promotion) (Evaluation tool 1) (13). The theoretical rationale of the breastfeeding component of Baby Buddy smartphone app intervention was examined through application of the BCW (Evaluation tool 2) (14). The BCW has three inter-related concentric layers. The inner layer, the COM-B model (Capability, Opportunity and Motivation), helps understand the behaviour that needs to be changed. This layer is further divided into six sources of influence; psychological, physical, automatic, reflective, physical and social (14). The middle layer consists of nine possible intervention functions that could address gaps identified from using COM-B. These interventions are; restrictions, education, persuasion, incentivisation, coercion, training, enablement, modelling and environmental restructuring (14). The outer layer of the BCW assists with identifying which policy opportunities could be utilised to support the delivery of the chosen interventions, guidelines, environmental and social planning, communication and marketing, legislation, service provision, regulation and fiscal measures (14). To complete the analysis we used The Behaviour Change Techniques Taxonomy (BCTTv1). This tool describes 93 behaviour change techniques that can deliver the intervention functions we identified (Evaluation tool 3) $(13,14)$.

\section{Application Of Tools}

Evaluation tool 1: Review of the Digital Behaviour Change Interventions (DBCls) development and evaluation process

The data supplied from Best Beginnings relating to the context (goals, opportunities, constraints, stakeholders, collaborators and risks) and the activities undertaken (concept, knowledge, development, testing, implementation and promotion) were examined in detail. This tool gave us insight into the choices that were made by Best Beginnings as the Baby Buddy project progressed (13).

Page $3 / 15$ 
Evaluation tool 2: Application of the Behaviour Change Wheel framework (BCW)

Once the key factors that Best Beginnings based their decisions on were clear, analysis of what needed to change was focused on. By mapping themes collected from the Best Beginnings data using the COM-B model, TDF and the intervention functions, it was evident that an intervention was required to change behaviour (14).

Evaluation tool 3: Describing the Behaviour Change Techniques Taxonomy (BCTTv1)

After the application of the BCW to the breastfeeding components, we described the 'active' ingredients that were used in the breastfeeding intervention using the BCTTV1 tool $(13,14)$. To do this we viewed and reviewed 39 videos, 8 glossary words ('What does that mean?) and 20 Baby Buddy generated responses to breastfeeding questions ('Ask me').

\section{Results}

Stage One - Understanding breastfeeding as a target behaviour

Step 1 - How breastfeeding was defined in behavioural terms

Data supplied by Best Beginnings showed that breastfeeding in behavioural terms was defined in behavioural terms - mothers using the app aged under 25 years, exclusively breastfeeding in every setting, starting within one hour after birth to six months of age.

Step 2 - How breastfeeding behaviours were selected

Best Beginnings defined the key issues in behavioural terms, selecting and then specifying target behaviours and then identifying what needed to change. The evidence reviewed by the research team that supported their analysis included:

1. The Infant Feeding Survey (2010) (5)

2. World Health Organization (WHO) Global Strategy for Infant and Young Child Feeding (Breastfeeding Manifesto) (15)

3. Tackling health inequalities in infant and maternal health outcomes (16)

4. Focus On: A Proportionate Approach to Priority Populations (17)

5. Fair Society, Healthy Lives - Strategic Review of Health Inequalities in England post 2010 (18)

6. The Foundation Years: preventing poor children becoming poor adults (19)

Our research team found that this literature supported the need for interventions to support women in their homes and communities through health services.

Best Beginnings had undertaken extensive consultation with stakeholders; implementers, funders and users. These include the funders and targeted users i.e. the UK Department of Health, UNICEF and women and their families. A strength of their process was that Best Beginnings worked with experienced market researchers. This was key to engaging with women and health care professionals. Documentation provided by Best Beginnings confirmed that a multidisciplinary team approach was adopted in the creation of the steering committee.

Seven target behaviours were found as a priority identified by Best Beginnings with regard to breastfeeding:

1. Increasing mothers' intentions to breastfeed

2. Giving advice on commencing breastfeeding

3. Giving information on correct positioning and attachment for breastfeeding

4. Knowing how to express breast milk

5. Knowing what is normal in the first few months of breastfeeding

6. Knowing how to overcome breastfeeding challenges

7. Planning to breastfeeding for six months or more

Step 3 - How target breastfeeding behaviours were specified

Breastfeeding behaviours were identified from data supplied by Best Beginnings. These were described in relation to: who, what, when, where, how often and with whom. Best Beginnings showed that they utilised mixed methods techniques to better understand the barriers and enablers affecting inequity, disparity and intergenerational disadvantage (Additional file 2). Health care professionals, parents and families were engaged as co-creators at all stages and were instrumental in app development, implementation, evaluation and promotion (20-24). Best Beginnings have followed best practice for selecting breastfeeding as a specific target behaviour and demonstrated a thorough understanding of the context.

Step 4 - Changes needed to support breastfeeding behaviours

Best Beginnings explored breastfeeding in terms of theoretical constructs that could be targeted by public health strategies to aid capability, opportunity and motivation. The review team examined reports, data and evaluations (Additional file 1) and found that a mixed methods approcah had informed the development and embedding process. Their approach consisted of focus groups, workshops, semi-structured interviews and surveys conducted with mothers, partners, midwives, nurses, doctors and academics. The data collected assisted Best Beginnings to identify both modifiable behavioural and non-modifiable behavioural barriers and enablers that needed to be addressed in the intervention elements. The COM-B model was used by the research team to understand breastfeeding in the context in which it occurs in.

\section{Physical And Psychological Capability}


Breastfeeding skill development was identified as a key enabler for both physical and psychological capability. Peer and clinical support, demonstrations, practice and feedback were identified as important to empower women to breastfeed. Best Beginnings had explored social norms, peer influence and the value of social support in sustaining breastfeeding. For example, women were asked to discuss breastfeeding in the context of their roles in their families, the presence or absence of support, the influences of cultural values, the impact of migration, isolation and loneliness. Percieved barriers such as difficulties positioning and attaching, low milk production (physical capability) and fear of failure, anxiety/depression (psychological capability) were identified as needing to be addressed by the intervention functions.

\section{Physical And Social Opportunity}

Support was identified as the primary enabler for both physical and social opportunity to breastfeed. Clinical/specialist, peer, community and technology support (apps, social media, online resources) were documented as facilitators for breastfeeding. Best Beginnings sought to understand environmental factors that may help, interfere or prevent breastfeeding efforts. Economic barriers and physical environment were discussed and several themes related to challenges in finding a way to initiate and maintain breastfeeding behaviours in the context of their roles as employees, mothers and partners. These barriers reported are consistent with reports in the literature particularly among women who describe a variety of challenges to breastfeeding such as fatique and infant/childcare demands (9).

\section{Reflective And Automatic Motivation}

Reflective motivation was identified as being related to decision making to breastfeed. The research team found that breastfeeding motivation is best facilitated by early planning, goal setting and positive belief reinforcement. Peer support normalises the challenges of breastfeeding and encourages selfdetermination. Support was documented as crucial to help alleviate negative thoughts or low confidence. Self-efficacy to change beliefs and habits and low health literacy barriers were explored to assess the ability of individuals to act on health advice and planned care and to uncover cultural specific values that may improve interventions in specific target groups. All of these barriers have been shown to have an impact on interventions that aim to improve a woman's ability to adopt healthy behaviours $(1,3)$.

After mapping the provided documentation, an in-depth analysis was conducted on the app content. The content of videos and text related to breastfeeding was catogorised using the COM-B model. A total of 39 videos, 8 glossary words ('What does that mean?) and 20 responses to breastfeeding questions ('Ask me') were examined in view of which intervention categories were used (Table 2).

Stage Two - Identifying how intervention functions were used

Step 5 - The intervention functions that were used

The middle layer of the BCW was used to identify which interventions were utilised to address the barriers and enablers identified in Step 4. The COM-B analysis of documentation and app content (Table 2) was used to map the intervention functions Best Beginnings used in the Baby Buddy content. For example; having the knowledge of how to attach and position the baby for breastfeeding was a theme identified by Best Beginnings from the focus group data. This is related to having the physical capability, knowledge and skills (relevant TDF) and education, modelling and enablement (intervention functions). Breastfeeding video content mapped to the BCW (COM-B, TDF and intervention functions) is shown in Table 3.

Step 6 - The policy categories that were used

The outer layer of the BCW was used to analyse the app development process. This enabled the identification of policies, guidelines, fiscal measures, service provision, legislation, regulation, communication or environmental opportunities that were used to deliver the breastfeeding intervention and embed the app into the UK health service (24).

The Baby Buddy app was designed to complement maternity and postnatal services. It has been endorsed by the Department of Health, Faculty of Public Health and the Royal Colleges of: Paediatrics and Child Health; Obstetricians and Gynaecologists; Midwives; Psychiatrists and Speech and Language Therapists; as well as the Community Practitioners and Health Visitors Association and the Institute of Health Visiting. The content of Baby Buddy was cocreated with parents and in consultation with stakeholders, for example, representatives from Royal Colleges and the Department of Health. No content is uploaded to Baby Buddy until representatives of all partners have given their approval.

Stage Three - Identifying how content and implementation choices were made

Step 7: How behaviour change techniques were used

Identification of BCTs was achieved by applying the BCTTv1 (Evaluation tool 3) to the content of the app. After each piece of content was categorised using the broad intervention categories, further analysis was carried out to identify exactly which BCTs were used (Table 3). These were then documented and specific examples and details given.

Step 8: Rationale for using Baby Buddy app as the mode of delivery

The APEASE criteria was used to evaluate if Best Beginnings had undertaken activities to ascertain acceptability, practicability, effectiveness, affordability, safety and equity (14). The evidence was analysed and judged against the previous DVD based breastfeeding intervention, 'Bump to breastfeeding and the 
'Small Wonders' DVD. In summary, Baby Buddy met the APEASE criteria for a viable digital intervention suitable for further testing, development and implementation (Additional file 2).

Market research was then undertaken to understand the need for an app in the context of other interventions that already existed in the UK. Workshops and focus groups conducted by Best Beginnings confirmed that there was a positive response from women to the concept of a mobile phone app. Positive factors of the app were thought to be; accessibility, everything in one place, fun and engaging, small 'bite sized' pieces of information, comprehensive and up-to-date information. Drivers to engage with the app were dependent on the age of the participants. Younger women, 15 to 18 years, were attracted to the fun elements of the app such as creating an avatar (Bump Buddy) and the gamification elements. Women over 18 years with a higher education level were more interested in the access to information a mobilie phone app might provide. Those who lacked access to healthcare or a personal network felt that the app would play both an informative and supportive role. Some of the younger women were concerned that they would not have access due to the type of phone they had or the additional cost.

Best Beginnings used a 'person based approach' to develop the look, feel and functionality of the app. Computer science was used to underpin the intervention development, such as; what was enjoyable, useful and also what the consumers wanted personalised. They also looked at the software in terms of decision support tools that could be used.

Breastfeeding content of the app is continually being revised and updated and has endorsement from several maternity health care experts and organisations. Maintaining credibility and sustainability of the app is heavily dependent on funding and participation of subject matter experts. This is led by a multidisciplinary editorial board of the charity that reviews all changes to content within the app.

Best Beginnings used Kotter's 8-Step process to guide implementation [17, 18]. This methodology, developed for change management involves an 8-Step process; 1) creating a sense of urgency, 2) building a guiding coalition, 3) forming a strategic vision and initiatives, 4) enlisting a volunteer army, 5) enabling action by removing barriers, 6$)$ generating short-term wins, 7$)$ sustaining acceleration and 8$)$ instituting change $(25,26)$.

In terms of promotion, the app is approved by the several key organisations including PHE and the Royal College of Midwives (RCM). Public relations are utilised well and there has been significant media coverage. Promotion strategies are discussed regularly with the advisory group and stakeholders. The app is freely available on the Apple App Store and Google Play and recently been embedded into maternity and early years care pathways through the National Health Service (NHS) $(21,23,27)$.

\section{Discussion}

The application of the BCW to the Baby Buddy shows that this app was designed as a usable and effective DBCl to change breastfeeding behaviours. Using the BCW to design behavioural change interventions in pregnancy leads to interventions that are acceptable, practical, effective, affordable, safe and address issues of equity. The use of participatory engagement and co-creation methods in development of a DBCl for breastfeeding can assist women to make decisions, effect attitudes and self-efficacy in relation to breastfeeding (13).

Our findings further support the work of Thomson et. al. (2019) and Crossland et. al. (2019) who found that Baby Buddy facilitated an increase in mother's knowledge and building confidence. This focus on relationship-building activities was perceived by mothers as beneficial $(21,22,27)$. Our findings confirm those from the report of Cooper et. al. (2015) and Powell et. al. (2016) that Baby Buddy is feasible, attractive and could be beneficial for maternal and infant health $(20,24)$.

The most recent published evaluation of Baby Buddy, the BaBBLeS study (Bumps and Babies Longitudinal Study), measured maternal self-efficacy as the primary outcome. The authors found that there was no differences in the maternal self-efficacy outcomes. However, they did perform a post-hoc analysis of breastfeeding and documented a significant increase in "any breastfeeding" at one month (OR 3.08, 95\% Cl: 1.49-6.35) and in "exclusive breastfeeding" at three months (OR 1.79, 95\% Cl: 1.02-3.16) (23). This highlights the need to conduct research that measures the intended outcome of the behavioural change intervention/s embedded in Baby Buddy, for example; capability, opportunity and motivation in relation to breastfeeding.

In addition, further promising data has been documented in an evaluation report on a self-care project for parents using Just One Norfolk website and the Baby Buddy app. The primary outcome for this study was self-care behaviour and was measured by the Patient Activation Measurement score (PAM) using the adult PAM questionnaire. A level 1 PAM score indicates that the individual is 'disengaged', whereas a level 4 PAM score indicates the individual is 'maintaining behaviours', thus has greater behaviour activation. The average activation score increased by 5.6 points for parents using the Baby Buddy app, this increase was statistically significant $(p<0.01)$. The evaluators concluded that Baby Buddy is associated with an increase in self-efficacy $(28)$.

\section{Strengths And Limitations}

This study has several strengths. It was performed independently using best practice guidelines approaches. It included a three stage process using evaluation tools that have been widely tested on behavioural change interventions in health. The use of the BCW facilitated an in-depth analysis and was conducted by content experts. Using an informative framework offered valuable understandings of how to design future DBCls using apps. Retrospective application of these tools also enabled the research team to identify potential opportunities to use behavioural change techniques for future development of Baby Buddy to increase effectiveness. The qualitative data supplied to us from Best Beginnings was collected from many sources, some of which was market research. Although not conducted as scientific research, therefore not bound by ethics approval, we found that the processes used to collate and explore the data vigorous. 
Retrospective mapping of the BCW to the app development process was complex and required substantial input from Best Beginnings. The evaluation tools we used were predominantly designed for text rather than video content. From our assessment, videos within an app appears to be a powerful influence to support behaviour change in breastfeeding. The videos take a 'show how' rather than a didactic 'tell to' approach and feature a mixture of experts support parents and peer-to-peer voice. For example, body language shown by partners; empathy demonstrated by clinicians and selection of images that demonstrate positive reinforcement. However, as the tools were not designed for video discourse analysis specifically, it was difficult to capture every BCT despite viewing the videos multiple times.

The development and evaluation of complex behaviour change interventions often consist of activities that can't be specified in advance because what happens next depends on the data that is collected (13). DBCls require frequent testing and due to the high-speed nature of technology complete trials are often not carried out as development moves quickly to implementation (13). Despite, or perhaps secondary to these issues, it is crucial to undertake robust research to determine the effectiveness on health outcomes of mobile phone applications. This is particularly relevant when considering their high use by young women and women from vulnerable groups.

\section{Conclusion}

Our work highlights the need to conduct high quality research and measure the clinical outcomes for which a digital behaviour change intervention was designed. In the case of the breastfeeding component of Baby Buddy, considering the effect on rates and duration of exclusive breastfeeding is an important variable to measure.

Baby Buddy is an example of what can be achieved when best practice in implementation science is followed. Understanding the barriers and enablers that affect breastfeeding behaviours is important when designing a DBCl that is intended to reduce disparity and intergenerational disadvantage. Baby Buddy is unique in its combination of endorsed content, friendly 'chatty' style, and practical, interactive features. Baby Buddy focuses on empowering young mothers, as well as increasing their knowledge, improving confidence, enhancing bonding and attachment and reinforcing the importance of accessing health services. Although the Baby Buddy app was not developed 'a-priori' using a named theoretical behaviour change framework, it was informed by behaviour changing thinking and the process aligns well to the BCW and is a sound platform for a breastfeeding intervention.

\section{List Of Abbreviations}

BCW - Behaviour Change Wheel

BCT - Behaviour Change Techniques

BCTTv1 - Behaviour Change Techniques Taxonomy

COM-B - Capability, Opportunity and Motivation-Behaviour

DBCl - Digital Behaviour Change Intervention

MRC - Medical Research Council

NHS - National Health Service

NICE - The National Institute for Health and Care Excellence

TDF - Theoretical Domains Framework

UK - United Kingdom

WHO - World Health Organisation

\section{Declarations}

\section{Ethics approval and consent to participate}

This project reviewed publically available reports or de-identified data that was collected as market research for the purpose of the app development. Ethics was not required.

\section{Consent for publication}

Not applicable

\section{Availability of data and materials}

The datasets used and/or analysed during the current study are available from the corresponding author on reasonable request.

\section{Competing interests}


$A B$ is the CEO and founder of Best Beginnings (UK). NP is the evaluation and impact lead at Best Beginnings (UK). All other authors are Australian researchers and declare that they have no competing interests.

\section{Funding}

The authors disclose that LM is funded by a University of Sydney, Charles Perkins Centre, Ho Man Kong and Ho Cheng Fung Ying Memorial postgraduate research scholarship. This manuscript has no direct funding support.

\section{Authors' contributions}

This project was conducted at the University of Sydney as part of a Doctorate of Philosophy. LM and AG contributed to the concept and design of the study. LM and AG conducted the research and analysed the data. LM drafted the first version of the manuscript. AB, NP and $\mathrm{CH}$ contributed to writing and editing the manuscript. All authors read and approved the final manuscript.

\section{Acknowledgements}

Not applicable

\section{References}

1. Rollins NC, Bhandari N, Hajeebhoy N, Horton S, Lutter CK, Martines JC, et al. Why invest, and what it will take to improve breastfeeding practices? Lancet. 2016;387(10017):491-504.

2. Victora CG, Bahl R, Barros AJD, França GVA, Horton S, Krasevec J, et al. Breastfeeding in the 21st century: epidemiology, mechanisms, and lifelong effect. The Lancet. 2016;387(10017):475-90.

3. Victora CG, Bahl R, Barros AJ, Franca GV, Horton S, Krasevec J, et al. Breastfeeding in the 21st century: epidemiology, mechanisms, and lifelong effect. Lancet. 2016;387(10017):475-90.

4. Horta BL, Loret de Mola C, Victora CG. Long-term consequences of breastfeeding on cholesterol, obesity, systolic blood pressure and type 2 diabetes: a systematic review and meta-analysis. Acta Paediatr. 2015;104(467):30-7.

5. McAndrew FTJ, Fellows L, Large A, Speed M, Renfrew MJ. Infant Feeding Survey 2010. Leeds: Health and Social Care Information Centre; 2012.

6. England PH. Official Statistics Breastfeeding prevalence at 6-8 weeks after birth (Experimental Statistics) Quarter $32019 / 20$ Statistical Commentary (January 2020) UK2019 [20 March 2020]. Available from:

https://assets.publishing.service.gov.uk/government/uploads/system/uploads/attachment_data/file/860224/2019_2020_Q2_Breastfeeding_Statistical_C

7. UNICEF UK BFI. Breastfeeding in England UK2019 [cited 30 May 2019]. Available from: https://www.unicef.org.uk/babyfriendly/about/breastfeeding-inthe-uk/breastfeeding-in-england/.

8. UNICEF. Unicef UK Baby Friendly Initiative. (2016) Protecting Health and Saving Lives: A Call to Action United Kingdom: UNICEF UK; 2016 [cited 2019]. Available from:

9. Asiodu IV, Waters CM, Dailey DE, Lee KA, Lyndon A. Breastfeeding and use of social media among first-time African American mothers. J Obstet Gynecol Neonatal Nurs. 2015;44(2):268-78.

10. Daly LM, Horey D, Middleton PF, Boyle FM, Flenady V. The Effect of Mobile App Interventions on Influencing Healthy Maternal Behavior and Improving Perinatal Health Outcomes: Systematic Review. JMIR mHealth uHealth. 2018;6(8):e10012-e.

11. Overdijkink SB, Velu AV, Rosman AN, van Beukering MD, Kok M, Steegers-Theunissen RP. The Usability and Effectiveness of Mobile Health TechnologyBased Lifestyle and Medical Intervention Apps Supporting Health Care During Pregnancy: Systematic Review. JMIR mHealth uHealth. 2018;6(4):e109-e.

12. Krishna S, Boren SA, Balas EA. Healthcare via cell phones: a systematic review. Telemedicine Journal E-Health. 2009;15(3):231-40.

13. West R, Michie S. A Guide to Development and Evaluation fo Digital Behaviour Change Interventions in Healthcare. 1st ed. London: Silverback Publishing; 2016.

14. Michie S, Atkins L, West R. The Behaviour Change Wheel-a guide to designing interventions. Great Britain: Silverback; 2014.

15. WHO. Global Strategy for infant and young child feeding. Singapore: WHO Library Cataloguing-in-Publication Data 2003 Contract No.: 28 August.

16. UK DoH. Tackling health inequalities in infant and maternal health outcomes report. London: Department of Health UK, Team IMNS; 2010.

17. Lu DTI. Focus on: A proportionate approach to priority populations. Toronto: Queen's Printer for Ontario; 2015.

18. Marmot M. Fair, Society. Healthy Lives - Strategic Review of Health Inequalities in England post-2010. 2010.

19. Field F. The Foundation Years: preventing poor children becoming poor adults. UK: 2010.

20. Cooper S. App Pilot Evaluation Report: National in-app data \& in-app data from Guys and St Thomas' and Blackpool. Reporting period: 19 November 2014 to 19 May 2015. London: Best Beginnings, 2015 August 2015. Report No.

21. Crossland N, Thomson G, Moran VH. Embedding supportive parenting resources into maternity and early years care pathways: a mixed methods evaluation. BMC Pregnancy and Childbirth. 2019;19(1). 
22. Thomson G, Crossland N. Using the behaviour change wheel to explore infant feeding peer support provision; insights from a North West UK evaluation. International breastfeeding journal. 2019;14(1):41.

23. Deave T, Ginja S, Goodenough T, Bailey E, Piwek L, Coad J, et al. The Bumps and BaBies Longitudinal Study (BaBBLeS): a multi-site cohort study of firsttime mothers to evaluate the effectiveness of the Baby Buddy app. mHealth. 2019;5:42.

24. Powell S, Ali Z, Christie S, Apps J, Goouch K. Report on the Evaluation of Baby Buddy M-Health Intervention with a focus on the GSTT Pilot Embedding Site. UK: Research Centre for Children, Families and Communities, Canterbury Christ Church University; 2016.

25. Kotter JP. Leading change. Boston: Harvard Business School Press; 1996.

26. Kotter JP. 8 Steps to accelerate change in your organization: Kotter Inc; 2018. Available from: https://www.kotterinc.com/wp-content/uploads/2019/04/8Steps-eBook-Kotter-2018.pdf.

27. Crossland N, Thomson G, Moran VH. Evaluation of Best Beginnings Resources. UK: 2018.

28. Service TUoEHaCR. Self Care Project for Parents using Just One Norfolk website and the Baby Buddy app (Final report)2020. Available from: https://www.bestbeginnings.org.uk/Handlers/Download.ashx?IDMF=3e40c2d6-9b0a-4606-8d3e-28f49ddd0ab5.

\section{Tables}

Table 1: Specifing breastfeeding as the target behaviour

\begin{tabular}{|c|c|}
\hline Who needs to perform the behaviour? & $\begin{array}{l}\text { Women, with a focus on young women under } 25 \text { years intending to } \\
\text { breastfeed }\end{array}$ \\
\hline What does the person need to do differently to achieve the desired change? & Offer breast first \\
\hline When will they do it? & Within the first hour of birth and then for every feed demanded \\
\hline Where will they do it? & At birthplace and then anywhere they choose to feed the infant \\
\hline How often will they do it? & Every feed \\
\hline With whom will they do it? & $\begin{array}{l}\text { With the support of staff initially and then independently with the support } \\
\text { of family and friends or professionals if required }\end{array}$ \\
\hline
\end{tabular}

Table 2: Breastfeeding app content mapping using COM-B 


\begin{tabular}{|c|c|c|c|c|c|c|}
\hline & \multicolumn{2}{|l|}{ Capability } & \multicolumn{2}{|c|}{ Opportunity } & \multicolumn{2}{|l|}{ Motivation } \\
\hline & Physical & Psychological & Social & Physical & Reflective & Automatic \\
\hline \multicolumn{7}{|l|}{ Video title } \\
\hline $\begin{array}{l}\text { Breastfeeding as a } \\
\text { young mum }\end{array}$ & 1 & I & 1 & 1 & 1 & 1 \\
\hline A practical choice & 1 & ) & 1 & 1 & ) & 1 \\
\hline $\begin{array}{l}\text { Feelings about } \\
\text { breastfeeding }\end{array}$ & 1 & ) & 1 & ) & ) & 1 \\
\hline $\begin{array}{l}\text { What's so good } \\
\text { about } \\
\text { breastfeeding? }\end{array}$ & & I & 1 & 1 & I & 1 \\
\hline $\begin{array}{l}\text { What if I bottlefed } \\
\text { before? }\end{array}$ & 1 & I & 1 & I & I & 1 \\
\hline $\begin{array}{l}\text { Asking for help to } \\
\text { get started }\end{array}$ & 1 & ) & l & ) & & \\
\hline $\begin{array}{l}\text { What will my } \\
\text { partner think? }\end{array}$ & & & 1 & & 1 & \\
\hline $\begin{array}{l}\text { Your first milk - } \\
\text { colostrum }\end{array}$ & 1 & I & & & I & 1 \\
\hline $\begin{array}{l}\text { Your baby's first } \\
\text { feed }\end{array}$ & 1 & I & 1 & ) & & 1 \\
\hline Skin to skin & I & ו & 1 & ו & & 1 \\
\hline $\begin{array}{l}\text { Good positioning } \\
\text { tips from a } \\
\text { midwife }\end{array}$ & 1 & & 1 & & & 1 \\
\hline $\begin{array}{l}\text { Getting the } \\
\text { position right }\end{array}$ & 1 & & & 1 & & 1 \\
\hline $\begin{array}{l}\text { Good positioning } \\
\text { demonstration }\end{array}$ & 1 & I & & 1 & I & \\
\hline $\begin{array}{l}\text { Keeping your baby } \\
\text { close }\end{array}$ & l & ) & l & ) & ) & ) \\
\hline $\begin{array}{l}\text { How dads can } \\
\text { help - Lenny }\end{array}$ & & & 1 & ) & & \\
\hline $\begin{array}{l}\text { Breastfeeding out } \\
\text { and about }\end{array}$ & & I & l & & ) & ) \\
\hline $\begin{array}{l}\text { When and how } \\
\text { often should I feed } \\
\text { my baby? }\end{array}$ & 1 & I & 1 & 1 & I & 1 \\
\hline $\begin{array}{l}\text { How dads can } \\
\text { help - Andy }\end{array}$ & & & 1 & ) & ) & \\
\hline $\begin{array}{l}\text { Where can I find } \\
\text { support? }\end{array}$ & 1 & ) & 1 & 1 & ) & \\
\hline $\begin{array}{l}\text { Overcoming } \\
\text { mastitis }\end{array}$ & 1 & I & 1 & I & 1 & 1 \\
\hline $\begin{array}{l}\text { Support from } \\
\text { health } \\
\text { professionals }\end{array}$ & 1 & I & I & ) & I & I \\
\hline $\begin{array}{l}\text { Some common } \\
\text { challenges }\end{array}$ & I & I & & ) & I & \\
\hline $\begin{array}{l}\text { Good and bad } \\
\text { attachment } \\
\text { graphic }\end{array}$ & I & & & I & & \\
\hline $\begin{array}{l}\text { Breastfeeding to a } \\
\text { year and beyond }\end{array}$ & I & I & 1 & I & I & 1 \\
\hline $\begin{array}{l}\text { Why breastfeed } \\
\text { for at least six } \\
\text { months? }\end{array}$ & 1 & 1 & 1 & I & I & ו \\
\hline $\begin{array}{l}\text { Breastfeeding and } \\
\text { weening }\end{array}$ & 1 & I & 1 & 1 & I & 1 \\
\hline
\end{tabular}

Page 10/15 


\begin{tabular}{|c|c|c|c|c|c|c|}
\hline & Capability & & Opportunity & & & \\
\hline Why express? & ) & 1 & 1 & ו & 1 & ) \\
\hline $\begin{array}{l}\text { How to hand } \\
\text { express }\end{array}$ & ) & ) & & ) & I & ) \\
\hline $\begin{array}{l}\text { How to use a } \\
\text { breast pump }\end{array}$ & ) & & & ) & 1 & \\
\hline $\begin{array}{l}\text { Expressing when } \\
\text { you're back at } \\
\text { work }\end{array}$ & ) & 1 & & ) & ) & \\
\hline $\begin{array}{l}\text { Storing and using } \\
\text { expressed breast } \\
\text { milk }\end{array}$ & & & & ) & I & \\
\hline $\begin{array}{l}\text { Early challenges } \\
\text { with expressing } \\
\text { milk }\end{array}$ & ) & ) & & ) & ) & \\
\hline Your breast milk & ) & ) & 1 & ) & ) & ) \\
\hline $\begin{array}{l}\text { How skin-to-skin } \\
\text { contact can help } \\
\text { you express }\end{array}$ & I & ) & 1 & ו & I & ) \\
\hline $\begin{array}{l}\text { Using a breast } \\
\text { pump }\end{array}$ & I & & 1 & ו & I & \\
\hline $\begin{array}{l}\text { Expressing with a } \\
\text { breast pump and } \\
\text { storing your milk }\end{array}$ & ) & ) & 1 & ) & ) & ) \\
\hline $\begin{array}{l}\text { Colostrum - your } \\
\text { baby's first food }\end{array}$ & ) & 1 & & ) & & 1 \\
\hline $\begin{array}{l}\text { Signs your baby is } \\
\text { ready to feed } \\
\text { independently }\end{array}$ & & 1 & 1 & ) & ) & \\
\hline $\begin{array}{l}\text { Breastfeeding } \\
\text { twins or triplets }\end{array}$ & ) & & & ) & I & \\
\hline \multicolumn{7}{|l|}{$\begin{array}{l}\text { Text responses to } \\
\text { 'What does that } \\
\text { mean?' }\end{array}$} \\
\hline Blocked ducts & I & & & ) & & \\
\hline Colostrum & ) & & & & & \\
\hline Expressing milk & ו & & & ) & & \\
\hline Mastitis & I & & & ו & & \\
\hline Rooting reflex & I & & & & & \\
\hline Reflex & I & & & & & \\
\hline Skin-to-skin & ) & 1 & 1 & ) & & \\
\hline Sterilising & ו & & & ו & & \\
\hline \multicolumn{7}{|l|}{$\begin{array}{l}\text { Text responses to } \\
\text { questions - 'Ask } \\
\text { me' }\end{array}$} \\
\hline $\begin{array}{l}\text { What is expressing } \\
\text { milk? }\end{array}$ & ) & & & ) & & \\
\hline $\begin{array}{l}\text { How do I express } \\
\text { milk? }\end{array}$ & ) & & & ) & & \\
\hline $\begin{array}{l}\text { Can I carry on } \\
\text { breastfeeding } \\
\text { after returning to } \\
\text { work, college or } \\
\text { school? }\end{array}$ & ) & & & ) & & \\
\hline $\begin{array}{l}\text { Why do people say } \\
\text { 'breast is best'? }\end{array}$ & ) & 1 & 1 & & ) & \\
\hline $\begin{array}{l}\text { What do I need to } \\
\text { know about } \\
\text { breastfeeding? }\end{array}$ & & & & ) & & \\
\hline
\end{tabular}




\begin{tabular}{|c|c|c|c|c|c|c|}
\hline & Capability & & Opportunity & & Motivation & \\
\hline $\begin{array}{l}\text { How do I } \\
\text { breastfeed when } \\
\text { I'm out and about? }\end{array}$ & I & I & I & ו & I & \\
\hline $\begin{array}{l}\text { Why is } \\
\text { breastfeeding so } \\
\text { good for babies } \\
\text { and mums? }\end{array}$ & 1 & 1 & 1 & ) & 1 & \\
\hline $\begin{array}{l}\text { I'm breastfeeding. } \\
\text { Do I need to wake } \\
\text { my newborn to } \\
\text { feed? }\end{array}$ & I & & & ו & ו & \\
\hline $\begin{array}{l}\text { What is latching } \\
\text { on? }\end{array}$ & 1 & & & ) & & 1 \\
\hline $\begin{array}{l}\text { Why are my } \\
\text { breasts growing } \\
\text { and sore? }\end{array}$ & ) & & & ו & & \\
\hline $\begin{array}{l}\text { How can I mix } \\
\text { breastfeeding and } \\
\text { bottlefeeding? }\end{array}$ & ) & ) & I & ו & & \\
\hline $\begin{array}{l}\text { How do I know if } \\
\text { my baby is } \\
\text { hungry? }\end{array}$ & & & & ) & & 1 \\
\hline $\begin{array}{l}\text { How often should I } \\
\text { feed my baby? }\end{array}$ & ) & & ) & ) & & \\
\hline $\begin{array}{l}\text { What is } \\
\text { colostrum? }\end{array}$ & ו & & & & & \\
\hline $\begin{array}{l}\text { What is milk } \\
\text { 'coming in'? }\end{array}$ & ו & & & ) & & \\
\hline $\begin{array}{l}\text { What is skin-to- } \\
\text { skin? }\end{array}$ & ) & ) & ) & I & & 1 \\
\hline $\begin{array}{l}\text { What are blocked } \\
\text { ducts and } \\
\text { mastitis? }\end{array}$ & I & & & ר & & \\
\hline $\begin{array}{l}\text { What are the } \\
\text { different kinds of } \\
\text { breast pumps? }\end{array}$ & I & & & I & & \\
\hline $\begin{array}{l}\text { What is baby-led } \\
\text { attachment? }\end{array}$ & I & & & ) & & 1 \\
\hline $\begin{array}{l}\text { How do I know my } \\
\text { baby is getting } \\
\text { enough milk? }\end{array}$ & ) & & & ) & & \\
\hline
\end{tabular}

Table 3: Data collection mapping worksheet 


\begin{tabular}{|c|c|c|c|c|c|c|}
\hline \multicolumn{7}{|c|}{ Using the Behaviour Change Wheel (BCW) to analyse breastfeeding video content in Baby Buddy } \\
\hline COM-B & COM-B Component & $\begin{array}{l}\text { Relevant } \\
\text { Theoretical } \\
\text { Domains } \\
\text { Framework (TDF) }\end{array}$ & $\begin{array}{l}\text { Description of } \\
\text { what needs } \\
\text { addressing in the } \\
\text { intervention based } \\
\text { on the data } \\
\text { collected }\end{array}$ & $\begin{array}{l}\text { Intervention } \\
\text { functions }\end{array}$ & $\begin{array}{l}\text { Behaviour change } \\
\text { techniques (BCTs) } \\
\text { identified }\end{array}$ & $\begin{array}{l}\text { Number of videos } \\
\text { containing the } \\
\text { BCTs }\end{array}$ \\
\hline \multirow[t]{14}{*}{ Capability } & Physical capability & Physical skills & $\begin{array}{l}\text { 1. Having the } \\
\text { physiological } \\
\text { ability to lactate }\end{array}$ & Education & $\begin{array}{l}4.1 \text { Instruction on } \\
\text { how to perform the } \\
\text { behaviour }\end{array}$ & 19 \\
\hline & & & $\begin{array}{l}\text { 2. Having the } \\
\text { physical capability } \\
\text { and skills to } \\
\text { breastfeed and } \\
\text { express milk }\end{array}$ & Training & $\begin{array}{l}6.1 \text { Demonstration } \\
\text { of the behaviour }\end{array}$ & 19 \\
\hline & & & & Modelling & 7.1 Prompts/cues & 16 \\
\hline & & & & & $\begin{array}{l}8.1 \text { Behavioural } \\
\text { practice/rehearsal }\end{array}$ & 18 \\
\hline & & & & & 9.1 Credible source & 19 \\
\hline & $\begin{array}{l}\text { Psychological } \\
\text { capacity }\end{array}$ & Knowledge & $\begin{array}{l}\text { 1. Knowledge } \\
\text { about the benefits } \\
\text { of breastfeeding }\end{array}$ & Education & $\begin{array}{l}\text { 1.2 Problem } \\
\text { solving }\end{array}$ & 13 \\
\hline & & $\begin{array}{l}\text { Cognitive and } \\
\text { interpersonal skills }\end{array}$ & $\begin{array}{l}\text { 2. Knowledge of } \\
\text { how to attach and } \\
\text { position the baby } \\
\text { for breastfeeding }\end{array}$ & Training & $\begin{array}{l}\text { 2.3 Self-monitoring } \\
\text { of behaviour }\end{array}$ & 14 \\
\hline & & $\begin{array}{l}\text { Memory, attention } \\
\text { and decision } \\
\text { processes }\end{array}$ & $\begin{array}{l}\text { 3. Ability to } \\
\text { problem solve and } \\
\text { make decisions } \\
\text { related to } \\
\text { breastfeeding }\end{array}$ & Modelling & $\begin{array}{l}4.1 \text { Instruction on } \\
\text { how to perform the } \\
\text { behaviour }\end{array}$ & 17 \\
\hline & & $\begin{array}{l}\text { Behavioural } \\
\text { regulation }\end{array}$ & $\begin{array}{l}\text { 4. Belief in ability } \\
\text { to produce } \\
\text { required amount of } \\
\text { breast milk and to } \\
\text { breastfeed } \\
\text { successfully }\end{array}$ & Persuasion & $\begin{array}{l}5.1 \text { Information } \\
\text { about health } \\
\text { consequences }\end{array}$ & 18 \\
\hline & & & $\begin{array}{l}\text { 5. Increase } \\
\text { confidence in } \\
\text { ability to } \\
\text { breastfeed }\end{array}$ & Enablement & $\begin{array}{l}5.3 \text { Information } \\
\text { about social and } \\
\text { environmental } \\
\text { consequences }\end{array}$ & 13 \\
\hline & & & $\begin{array}{l}\text { 6. Beliefs about } \\
\text { the consequences } \\
\text { of not } \\
\text { breastfeeding e.g. } \\
\text { regret, feeling a } \\
\text { failure as a mother }\end{array}$ & & $\begin{array}{l}6.1 \text { Demonstration } \\
\text { of the behaviour }\end{array}$ & 16 \\
\hline & & & $\begin{array}{l}\text { 7. Conscious } \\
\text { decision to } \\
\text { breastfeed } \\
\text { successfully }\end{array}$ & & 7.1 Prompts/cues & 14 \\
\hline & & & $\begin{array}{l}\text { 8. Increase ability } \\
\text { to deal with } \\
\text { emotions related } \\
\text { to breastfeeding } \\
\text { e.g. anxiety about } \\
\text { capacity }\end{array}$ & & $\begin{array}{l}8.1 \text { Behavioural } \\
\text { practice/rehearsal }\end{array}$ & 16 \\
\hline & & & & & 9.1 Credible source & 17 \\
\hline \multirow[t]{2}{*}{ Opportunity } & $\begin{array}{l}\text { Physical } \\
\text { opportunity }\end{array}$ & $\begin{array}{l}\text { Environmental } \\
\text { context and } \\
\text { resources }\end{array}$ & $\begin{array}{l}\text { 1. Perception that } \\
\text { breastfeeding is } \\
\text { difficult due to the } \\
\text { unpredictable } \\
\text { nature of demand } \\
\text { feeding }\end{array}$ & Education & $\begin{array}{l}4.1 \text { Instruction on } \\
\text { how to perform the } \\
\text { behaviour }\end{array}$ & 17 \\
\hline & & & $\begin{array}{l}\text { 2. Having } \\
\text { unlimited access } \\
\text { to the well infant } \\
\text { or demand feeding }\end{array}$ & Enablement & 7.1 Prompts/cues & 12 \\
\hline
\end{tabular}




\begin{tabular}{|c|c|c|c|c|c|c|}
\hline & & & & $\begin{array}{l}\text { Environmental } \\
\text { restructuring }\end{array}$ & $\begin{array}{l}12.1 \text { Restructuring } \\
\text { the physical } \\
\text { environment }\end{array}$ & 9 \\
\hline & & & & & $\begin{array}{l}12.2 \text { Restructuring } \\
\text { the social } \\
\text { environment }\end{array}$ & 5 \\
\hline & & & & & $\begin{array}{l}12.3 \\
\text { Avoidance/reducin } \\
\text { g exposure to cues } \\
\text { for the behaviour }\end{array}$ & 4 \\
\hline & Social opportunity & Social influences & $\begin{array}{l}\text { 1. Perception that } \\
\text { breastfeeding is } \\
\text { difficult }\end{array}$ & Education & $\begin{array}{l}\text { 2.3 Self-monitoring } \\
\text { of behaviour }\end{array}$ & 14 \\
\hline & & & $\begin{array}{l}\text { 2. Encouragement } \\
\text { from health care } \\
\text { professionals }\end{array}$ & Persuasion & $\begin{array}{l}5.1 \text { Information } \\
\text { about health } \\
\text { consequences }\end{array}$ & 11 \\
\hline & & & $\begin{array}{l}\text { 3. Support of } \\
\text { friends, family and } \\
\text { community }\end{array}$ & Modelling & $\begin{array}{l}5.3 \text { Information } \\
\text { about social and } \\
\text { environmental } \\
\text { consequences }\end{array}$ & 14 \\
\hline & & & $\begin{array}{l}\text { 4. Holds the belief } \\
\text { that exclusive } \\
\text { breastfeeding is } \\
\text { socially acceptable } \\
\text { and culturally } \\
\text { normal }\end{array}$ & $\begin{array}{l}\text { Environmental } \\
\text { restructuring }\end{array}$ & $\begin{array}{l}6.3 \text { Information } \\
\text { about other's } \\
\text { approval }\end{array}$ & 9 \\
\hline & & & & & 7.1 Prompts/cues & 2 \\
\hline & & & & & 9.1 Credible source & 7 \\
\hline & & & & & $\begin{array}{l}12.2 \text { Restructuring } \\
\text { the social } \\
\text { environment }\end{array}$ & 6 \\
\hline Motivation & $\begin{array}{l}\text { Reflective } \\
\text { motivation }\end{array}$ & $\begin{array}{l}\text { Professional/socia } \\
\text { I role and identity }\end{array}$ & $\begin{array}{l}\text { 1.Don't like the } \\
\text { idea of needing or } \\
\text { seeking help/belief } \\
\text { that women } \\
\text { should be able to } \\
\text { breastfeed } \\
\text { 'naturally' }\end{array}$ & Education & $\begin{array}{l}5.5 \text { Anticipated } \\
\text { regret }\end{array}$ & 6 \\
\hline & & $\begin{array}{l}\text { Beliefs and } \\
\text { capabilities }\end{array}$ & $\begin{array}{l}\text { 2.Needing help } \\
\text { with breastfeeding } \\
\text { means there is a } \\
\text { problem }\end{array}$ & Persuasion & $\begin{array}{l}5.6 \text { Information } \\
\text { about emotional } \\
\text { consequences }\end{array}$ & 16 \\
\hline & & Optimism & $\begin{array}{l}\text { 3.Disappointment } \\
\text { with self if unable } \\
\text { to breastfeed }\end{array}$ & Modelling & $\begin{array}{l}11.2 \text { Reduce } \\
\text { negative emotions }\end{array}$ & 9 \\
\hline & & $\begin{array}{l}\text { Beliefs about } \\
\text { consequences }\end{array}$ & $\begin{array}{l}\text { 4.Believing that } \\
\text { breastfeeding is } \\
\text { the best method of } \\
\text { feeding }\end{array}$ & & $\begin{array}{l}13.2 \text { Framing/re- } \\
\text { framing }\end{array}$ & 14 \\
\hline & & Intentions & $\begin{array}{l}\text { 5. Want to } \\
\text { breastfeed this } \\
\text { time as bottle fed } \\
\text { last time }\end{array}$ & & $\begin{array}{l}13.5 \text { Identity } \\
\text { associated with } \\
\text { changed behaviour }\end{array}$ & 13 \\
\hline & & Goals & & & $\begin{array}{l}15.3 \text { Focus on past } \\
\text { success }\end{array}$ & 2 \\
\hline & $\begin{array}{l}\text { Automatic } \\
\text { motivation }\end{array}$ & Reinforcement & $\begin{array}{l}\text { 1.Emotionally } \\
\text { driven to } \\
\text { breastfeed } \\
\text { because of the } \\
\text { benefits } \\
\text { associated such } \\
\text { as bonding and } \\
\text { attachment }\end{array}$ & Education & $\begin{array}{l}4.2 \text { Information } \\
\text { about antecedents }\end{array}$ & 10 \\
\hline & & Emotion & $\begin{array}{l}\text { 2. Fear of failing to } \\
\text { breastfeed } \\
\text { successfully }\end{array}$ & Incentivization & $\begin{array}{l}5.1 \text { Information } \\
\text { about health } \\
\text { consequences }\end{array}$ & 15 \\
\hline & & & & Modelling & $\begin{array}{l}5.2 \text { Salience of } \\
\text { consequences }\end{array}$ & 18 \\
\hline
\end{tabular}




\begin{tabular}{|c|c|c|}
\hline \multicolumn{3}{|l|}{ Using the Behaviour Change Wheel (BCW) to analyse breastfeeding video content in Baby Buddy } \\
\hline Persuasion & $\begin{array}{l}5.3 \text { Information } \\
\text { about social and } \\
\text { environmental } \\
\text { consequences }\end{array}$ & 17 \\
\hline & $\begin{array}{l}5.6 \text { Information } \\
\text { about emotional } \\
\text { consequences }\end{array}$ & 16 \\
\hline & $\begin{array}{l}6.3 \text { Information } \\
\text { about other's } \\
\text { approval }\end{array}$ & 11 \\
\hline & $\begin{array}{l}\text { 8.1 Behavioural } \\
\text { practice/rehearsal }\end{array}$ & 17 \\
\hline & $\begin{array}{l}\text { 8.3 Habit } \\
\text { formation }\end{array}$ & 16 \\
\hline & 9.2 Pros and cons & 16 \\
\hline & $\begin{array}{l}11.2 \text { Reduce } \\
\text { negative emotions }\end{array}$ & 15 \\
\hline & $\begin{array}{l}13.2 \\
\text { Framing/reframing }\end{array}$ & 19 \\
\hline
\end{tabular}

\section{Figures}

\begin{tabular}{|c|c|c|}
\hline \multicolumn{3}{|l|}{ Step 1: Document how breastfeeding wa: } \\
\hline $\begin{array}{l}\text { Step 2: Document how breastfeeding } \\
\text { behaviours were selected }\end{array}$ & $\begin{array}{l}\text { Step 5: Document which interventior } \\
\text { functions were used }\end{array}$ & $\begin{array}{l}\text { Stage Three - Indentifying how content } \\
\text { and implementation choices were made }\end{array}$ \\
\hline $\begin{array}{l}\text { Step 3: Document how target breastfeeding } \\
\text { behaviours were specified } \\
\text { Step 4: Document what needed to change to } \\
\text { support breastfeeding behaviours }\end{array}$ & $\begin{array}{l}\text { Step 6: Document which policy } \\
\text { categories were used }\end{array}$ & $\begin{array}{l}\text { Step 7: Document which behaviour change } \\
\text { techniques were used } \\
\text { Step 8: Document why Baby Buddy was used to } \\
\text { deliver the intervention }\end{array}$ \\
\hline
\end{tabular}

\section{Figure 1}

Process of applying the Digital Behaviour Change Interventions and Behaviour Change Wheel to Baby Buddy $(13,14)$.

\section{Supplementary Files}

This is a list of supplementary files associated with this preprint. Click to download.

- Additonalfile2BBAPEASE2020.docx

- Additionalfile1BBdatasupplied2020.docx 